\title{
Marokkansk demokratisk teater
}

\section{Julie Pruzan-Jørgensen}

\section{Valget var måske ikke nogen stor øvelse i demokra- ti, men den lave valgdeltagelse udstillede proble- merne i regimets officielle reformproces}

Parlamentsvalg i den arabiske verden er ikke kendt for at medføre større politiske forandringer og påkalder sig derfor sjældent større international bevågenhed. Det gjaldt dog ikke for det marokkanske parlamentsvalg den 7. september 2007, der forudgående var genstand for massiv international bevågenhed. Det skyldtes i særdeleshed to forhold.

For det første skønnes Marokko at være et af de 'demokratiske foregangslande' i Mellemøsten og Nordafrika, og der var derfor store forventninger til valgets demokratiske karakter. Marokko har i de senere år under kong Mohamed VI's ledelse gennemgået en række politiske reformer, som betyder, at man i dag kan bevæge sig, klæde sig og endog udtale sig relativt frit i forhold til normen i det øvrige Mellemøsten og Nordafrika. Og der var forud for val- get udsendt et klart signal fra kongehuset om, at valget den 7. september skulle adskille sig fra tidligere tiders mere eller mindre frie og troværdige valghandlinger og dermed udgøre en afgørende begivenhed i landets 'demokratiske transition'.

Det marokkanske indenrigsministerium havde derfor i månederne op til valget brugt store ressourcer på at forberede valghandlingen ved blandt andet at træne valgtilforordnede, informere om valget og oprette nye stemmelokaler for dermed at lette befolkningens adgang til parlamentsvalget.

Den anden årsag til den store forudgående bevågenhed var, at de fleste meningsmålinger pegede på, at det moderate PJD parti (Retfærdighed og Udvikling) ville opnå meget væsentlig fremgang ved valget. I dagene inden valget blev PJD spået en fremgang fra 42 til helt op til mel- 
lem $70 \mathrm{og} 80$ af parlamentets 325 sæder. Dermed ville PJD blive både valgets sejrherre og parlamentets største politiske parti. Det ville i givet fald også være første gang, et islamistisk parti ville få lov at sejre ved et parlamentsvalg i Nordafrika siden den katastrofale FIS-sejr, der i 1991-92 kastede nabolandet Algeriet ud i 10 års blodig borgerkrig.

Men det kom langt fra til at gå som ventet. Til de fleste iagttageres store forbavselse opnåede PJD slet ikke de ventede resultater. Godt nok fik partiet en beskeden fremgang, men den var langt fra den ventede jordskredssejr, og partiet blev ikke parlamentets største parti. Som en endnu større overraskelse blev valgdeltagelsen rekordlav, idet der paradoksalt nok kun var 37 procent af marokkanerne, der valgte at stemme ved landets mest frie og transparente valg nogensinde.

Hvordan skal det overraskende valgresultat udlægges? Skal det forstås som et udtryk for, at islamiseringen i Marokko alligevel ikke er så gennemgribende, som hidtil antaget? Og hvad med den lave stemmeprocent? Hvad udtrykker den - og hvad er dens implikationer for det marokkanske regime, der havde lagt megen vægt på at gennemføre et transparent og folkeligt engagerende parlamentsvalg? Vil den lave stemmeprocent kunne true regimets hidtidige succesfulde balanceakt mellem at fastholde grundlæggende magtstrukturer parallelt med introduktion af en række begrænsede politiske reformer? Disse og andre spørgsmål diskuteres i den følgende analyse af parlamentsvalget $i$ Marokko, som tager sit afsæt i en række konkrete situationer og personlige observationer fra valgkampen.

\section{Sejren der udeblev}

PJD udspringer oprindeligt af en radikal og regimekritisk gruppe al-shabiba al-islamiyya (Islamisk Ungdom), men er gennem de seneste godt 15 år blevet en stadig mere moderat, demokratisk indstillet og regimevenlig politisk aktør. Partiet deltog for første gang i et marokkansk parlamentsvalg i 1997 og blev parlamentets tredje største parti ved det seneste parlamentsvalg i 2002, selvom det kun stillede op i et begrænset antal valgkredse.

Foruden de to store, erklærede ikke-voldelige islamistiske bevægelser i Marokko, PJD og al adl wal ihsan (Retfærdighed og Godgørenhed) findes der en underskov af radikale islamistiske grupperinger. En sådan gruppe fra slumkvarteret Sidi Moumen gennemførte den 16. maj 2003 den første større islamistisk inspirerede terroraktion i Marokko, hvor 14 unge selvmordsbombere sprang sig selv og 33 ofre i luften ved en række vestlige og jødiske mål i Casablanca.

Selvom PJD var uden forbindelse til de unge terrorister, blev partiet $\mathrm{i}$ 
kølvandet på terrorbomberne udsat for omfattende kritik og måtte kæmpe for sin fortsatte eksistensberettigelse på den tilladte politiske scene i Marokko. Det medførte udrensning af de mest markante og stridbare figurer i partiets ledelse samt modifikationer af partiets diskurs.

I dag fungerer PJD som et velorganiseret politisk parti og en væsentlig aktør i det marokkanske parlament. Partiet fremstår som en pendant til navnebroderen AKP i Tyrkiet og dets islam light, idet PJD fortsat lægger stor vægt på religion og moral, men i øvrigt primært arbejder for at fremme en social liberal politik, der i første omgang skal begrænse den udbredte korruption og nepotisme i Marokko. Mange af dets ledere er særdeles højtuddannede, og partiet appellerer særligt til middelklassen i de større marokkanske byer. PJD er et af de partier, der har flest kvindelige parlamentarikere, og det har i de senere år tiltrukket mange yngre kvindelige tilhængere.

Dette var helt evident den 6. september på valgkampens sidste aften, som jeg tilbragte sammen med en gruppe af partiets aktivister i Rabat. Optimismen var ikke til at tage fejl af. Som altid var partiets tilhængere opdelt i køn. Men dette lagde på ingen måde låg på begejstringen blandt unge, tilhyllede kvinder i lange cowboynederdele, der begejstrede udråbte partiets slogan, ifølge hvilket en stemme på PJD vil få en lampe (partiets logo) til at lyse lan- det op. Disse unge kvinder holdt sig bestemt ikke tilbage og hujede og grinede gennem gaderne, hvor de modtog mange venlige smil og hilsener fra befolkningen.

Men deres optimisme varede ikke ved. Ved valget den efterfølgende dag fik PJD langt fra den ventede jordskredssejr. Godt nok gik partiet fire mandater frem fra valget i 2002 og vandt dermed 46 af parlamentets 325 sæder, men det var langt fra de 70-80 mandater, som ledelsen havde håbet på. PJD blev end ikke Marokkos største parti, idet det gamle nationalt konservative uafhængighedsparti, Istiqlal, blev valgets sejrherre med 52 mandater. Det kom som en stor overraskelse, at Istiqlal opnåede så godt et resultat, da partiet er en del af den meget udskældte, afgående regeringskoalition.

Det er endnu for tidligt at fælde en endelig dom over resultatet, men at dømme efter de umiddelbare reaktioner har der formentlig været en række forskellige årsager til det overraskende udfald.

I de snævre gader i den gamle medina i Rabat opstod der hurtigt et rygte om, at der simpelthen traditionen tro måtte være fiflet med stemmerne, på trods af regimets gentagne udmeldinger om, at dette valg for første gang ville blive afholdt $i$ fuld åbenhed. I medinaen fandt man det simpelthen utænkeligt, at Istiqlal skulle være mere populært end PJD. Rygtet gik derfor, at man i Indenrigsministeriet traditionen tro 
havde ændret på stemmetallene for at undgå, at PJD skulle blive valgets sejrherre.

En anden udlægning af nederlaget kom fra PJD's ledelse, som ikke anfægtede selve valgdagens handlinger, men anklagede Istiqlal for at have købt sig til en sejr ved at bestikke vælgere til at stemme på partiet forud for valgdagen.

Begge disse anklager syntes dog efterfølgende affejet af udmeldingerne fra både marokkanske og internationale valgobservatører, som på trods af en ganske lang række enkeltstående forhold overordnet har konkluderet, at det marokkanske parlamentsvalg forløb gennemsigtigt og korrekt. Men hvis udfaldet ikke kan forklares med systematiske uregelmæssigheder - hvordan kunne det så gå til, at PJD opnåede et resultat, der lå så langt fra de forudgående prognoser? En konklusion kunne være, at PJD-resultatet indikerer, at islamiseringen måske alligevel ikke er så gennemgribende i Marokko, som hidtil antaget?

\section{Islamisering overvurderet?}

Det marokkanske valgresultat kan ikke udlægges som et simpelt nederlag for 'islam' eller som udtryk for et ønske om sekularisering i den marokkanske befolkning. Valgets sejrherre, Istiqlal-partiet, har nemlig sine rødder i den salafistiske islamiske reformbevægelse og er i høj grad også baseret på et islamisk vær- digrundlag, om end af en mere nationalkonservativ og mindre aktivistisk karakter end PJD.

Men den primære årsag til, at man ikke bare kan antage at resultatet er et udtryk for, at islamiseringen er mindre gennemgribende i Marokko end hidtil antaget, skal findes i det forhold, at den største islamistiske og oppositionelle bevægelse i Marokko, den forbudte men indflydelsesrige al adl wal ihsan (Retfærdighed og Godgørenhed), slet ikke stillede op, men opfordrede de marokkanske vælgere til at boykotte parlamentsvalget.

Retfærdighed og Godgørenhed er inspireret af sufi-islam og var oprindeligt en religiøs og spirituel bevægelse forenet omkring grundlæggeren sheik Yassine. Den erklæret ikke-voldelige bevægelse har efterhånden udviklet sig til en væsentlig social aktør, der yder et betydningsfuldt religiøst og socialt arbejde blandt den fattige marokkanske underklasse. Bevægelsen har også stor indflydelse på de marokkanske universiteter og studenterorganisationer.

Indtil videre har Retfærdighed og Godgørenhed dog ikke forsøgt sig som et decideret politisk parti. Bevægelsen ville heller ikke have nemt ved at blive accepteret af regimet, da den problematiserer kongens og regimets autoritet. Det gælder i særdeleshed for bevægelsens talsmand, Nadia Yassine, som er datter af bevægelsens grundlægger. Hun er en 
kontroversiel figur og udfordrer mange vestlige forestillinger, idet hun på en og samme tid er tilsløret, islamist - og en højtuddannet kvindeforkæmper, som stortrives som fransktalende intellektuel. Nadia Yassine faldt for alvor i unåde i sommeren 2005, hvor hun i et interview åbent udtalte, at hun ville foretrække en republik frem for det nuværende marokkanske monarki.

I modsætning til Retfærdighed og Godgørenhed har PJD's ledende skikkelser på linje med alle de øvrige accepterede politiske partier eksplicit anerkendt kongens og regimets autoritet. De anerkender således, at den marokkanske konge er landets øverste politiske leder såvel som dets religiøse overhoved, som direkte nedstammer fra muslimernes profet Muhammed. Denne anerkendelse af regimets legitimitet har ført til den noget nedsættende betegnelse 'les islamistes du roi' kongens egne islamister.

Det er derfor ikke muligt at drage den simple konklusion, at valgresultatet er et udtryk for, at islamiseringen alligevel ikke er så gennemgribende i Marokko som hidtil antaget. Det er nemlig også en mulighed, at der faktisk er en meget stor andel af de marokkanske vælgere, der sympatiserer med de islamistiske bevægelser, men foretrækker Retfærdighed og Godgørenhed og derfor fulgte deres opfordring til at boykotte valget og dermed var blandt de 63 procent af de registrerede marok- kanske vælgere, der ikke benyttede deres stemmeret.

Endelig er der den mulighed, at det store befolkningsflertal simpelthen valgte at boykotte valget, fordi de hverken har tillid til PJD, til de øvrige politiske partier eller til det politiske system som sådan.

\section{Rekordlav valgdeltagelse}

Ingen udtrykte deres frustration og mistillid til valget så klart som den gamle dame, som jeg mødte på valgdagen den 7. september. Smykket med berbernes traditionelle ansigtstatoveringer og svøbt i en gammel, orange djellaba var hun en af de få, der faktisk havde begivet sig ud for at udnytte sin stemmeret - og var blevet ganske rystet over oplevelsen.

For det første havde hun ikke modtaget sit valgkort på trods af at have boet mere end 10 år i området. Hun havde derfor måttet bruge en masse energi, før det til sidst var lykkedes hende at overtale de valgforordnede til at lade hende stemme. Efterfølgende var hun blevet yderst forvirret over stemmesedlen hvor intet mindre end 33 partier havde angivet deres forskellige og højest særprægede valgsymboler. Det havde ikke gjort forvirringen mindre, at hvert symbol blev angivet to gange for at give vælgerne mulighed for at stemme på den særlige liste nationale for kvindelige kandidater.

Da den ældre dame - i lighed med mere end halvdelen af den 
øvige marokkanske befolkning heller ikke kunne læse, havde hun til sidst følt sig så forvirret, at hun havde bedt sin nabo om hjælp til at sætte sit kryds i stemmeboksen. Det var dog ikke blevet tilladt, og derfor havde hun sluttelig bare sat et stort kryds ud over hele suppedasen, og havde dermed afgivet en af valgets mange ugyldige stemmer. Sluttelig var hendes forargelse også stor over, at hun ikke var blevet bedt om at stikke sin tommelfinger i den blækklat, der tilkommer alle, der har stemt - hvorfor hun jo principielt kunne have stemt igen.

Jeg har viderebragt denne ældre dames frustration i mange detaljer, fordi den i sin enkle form afspejler den frustration og mistillid som mange almindelige marokkanere oplever i deres møde med det politiske system, der opfattes som korrupt, ineffektivt og uvedkommende i forhold til befolkningens massive sociale problemer.

Den folkelige kritik mod det politiske system er i vidt omfang vendt mod de politiske partier, der anklages for at savne klare og selvstændige politiske profiler. Et problem der accentueres af, at de fleste partier indgår i taktiske valgforbund, som ofte bidrager til yderligere at udvande de enkelte partiers budskaber og ideologisk linje. Således gik det sejrende Istiqlal til valg i koalition med to socialistiske partier, heriblandt valgets store taber, det socialistiske USFP. Historisk har denne alliance givet god mening, da de to partier op igennem 1980'erne fungerede som politisk opposition til det daværende meget repressive regime.

Men en sådan koalition i 2007 medvirker til i høj grad at forvirre vælgeren - og til at styrke befolkningens udbredte anklager om, at politikerne ikke arbejder for befolkningen, endsige for et politisk eller ideologisk projekt, men for at mele deres egen kage.

Hertil kommer, at den nye marokkanske valglov i høj grad bidrager til at underminere dannelsen af stærke politiske blokke og flertalsregeringer, idet såvel indførelsen af forholdstalsvalg som valgkredsenes sammensætning fremmer den partipolitiske 'balkanisering' og den deraf følgende nødvendighed af brede koalitionsregeringer. Der var hele 33 opstillede lister ved valget den 7 . september, hvoraf 24 havde held til at sikre repræsentation i den nye samling. Det ventes derfor, at den nye regering bliver en koalition som den afgående, der talte ikke mindre end fem forskellige partier - i tillæg til en række teknokrat-ministre, udpeget af kongen.

Og hermed nærmer vi os den måske allervæsentligste årsag til valgets udfald, nemlig den betydelige magtkoncentration i og omkring det marokkanske kongehus.

\section{Demokratisk teater}

Den 9. september befandt jeg mig 
til et frokostselskab for en række velbjærgede marokkanske direktørfruer. Også her gik diskussionen om valget - og også her var samtalen præget af mistillid over for det politiske system. Således overhørte jeg en længere diskussion mellem to damer, der drejede sig om, hvordan man bedst havde givet sin mistillid til kende ved valget - ved at stemme blankt, eller ved helt at undlade at stemme? Den underlæggende præmis for de to elegante damers samtale var en fuldkommen mangel på tillid ikke blot til de politiske partier, men også til selve valghandlingen, der under ingen omstændigheder sås som medførende reelle politiske forandringer.

Reelt er det da også den marokkanske konge, der styrer den til enhver tid siddende regering. Blandt kongens udstrakte forfatningsgivne rettigheder er retten til at udnævne såvel premierministeren som andre nøgleministre. Dette blev til fulde illustreret ved det seneste parlamentsvalg i 2002, hvor Mohamed VI valgte at overse valgets folkevalgte sejrherrer og i stedet udnævnte en ikke-folkevalgt teknokrat, erhvervsmanden Driss Jettou, som premierminister.

Endnu mere væsentligt er det, at langt de fleste centrale initiativer og beslutninger formuleres uden for det parlamentariske system i de kongelige kommissioner, fonde og af de indflydelsesrige kongelige rådgiveres 'skyggeregering', som i praksis styrer alle væsentlige politiske initia- tiver. En god illustration heraf er det store og omkostningstunge nationale 'human development' initiativ (INDH), som har været en af de væsentligste politiske nyskabelser i de seneste år. INDH har aldrig været på tegnebrættet hos de fem regerende partier, men blev i stedet foreslået regeringen fra paladset, hvorefter det blev den nu afgående regerings mærkesag.

\section{Fremskridt trods alt}

På trods af dets usædvanligt transparente afholdelse kan det marokkanske parlamentsvalg altså langt fra siges at udgøre en grundpille i Marokkos 'demokratiske transition'. Det synes tværtimod nærliggende at konkludere, at valget reelt blot var endnu et i rækken af arabiske potemkin-affærer: tomme demokratiske skueprocesser, hvor magten reelt ikke er på valg.

Men alligevel er det ikke helt rigtigt at konkludere sådan. For ét forhold adskiller alligevel det marokkanske valg fra de vante arabiske skueprocesser, nemlig den lave valgdeltagelse, som indikerer, at den marokkanske befolkning har opnået en vis politisk indsigt og har gennemskuet, at det ikke gør en reel forskel, hvem de stemmer på.

Og ikke mindst at den meget lave stemmedeltagelse faktisk blev offentliggjort, og befolkningens manglende interesse for og tillid til det politiske system dermed kom for dagen. 
Det lave stemmetal har vakt stor opsigt og givet anledning til grundig selvransagelse i Marokko. Ikke overraskende er skylden hurtigt blevet placeret primært hos de politiske partier og i anden række hos de marokkanske medier, som begge anklages for uklare budskaber og dårlig kommunikation. Men uanset at skylden søges placeret uden for Paladset, så lægger det lave stemmetal også et stort pres på regimet, da det i sidste ende står klart for de fleste iagttagere, at en revitalisering af det parlamentariske system og ikke mindst af befolkningens tillid til og interesse for de politiske partier forudsætter en begrænsning af paladsets magt til fordel for en styrkelse af parlamentets indflydelse og beslutningsmyndighed.

Det marokkanske kongehus har derfor taget et stort skridt ved at tillade, at valgets transparente karakter blev fuldbyrdet med offentliggørelsen af det rekordlave stemmetal. Den lave deltagelse har nemlig for alvor udstillet de indbyggede modsætninger og begrænsninger i regimets såkaldte 'demokratiske transition', hvor det hidtil med stor succes har introduceret en række afgrænsede politiske reformer, mens det har undgået politiske tiltag, der for alvor ville ændre på de politiske magtforhold. Denne balanceakt synes dog udfordret af befolkningens mistillidsvotum ved valget.

Det er endnu alt for tidligt at sige, hvorledes befolkningen, partierne og ikke mindst kongehuset vil reagere på denne nye situation. På kort sigt vil der formentlig ikke ske de helt store forandringer, idet der formentlig blot konstitueres en ny bred koalitionsregering, der i vidt omfang kommer til at ligne den afgående regering. Men det bliver meget spændende at følge, hvorvidt befolkningens politiske mistillidsvotum ved parlamentsvalget den 7. september 2007 på længere sigt vil øge presset for en forfatningsændring, der reelt vil ændre den politiske magtdeling i Marokko.

Julie Pruzan-Jørgensen er cand.scient.pol og ansat ved Dansk Institut for Internationale Studier (DIIS). Artiklen er afleveret inden den nye regering blev dannet.

\section{Udvalgt litteratur}

Aujourd'hui le Maroc, www.aujourdhui.ma Brumberg, Daniel: 'Democratization in the Arab World? The Trap of Liberalized Autocracy', Journal of Democracy, Vol. 13, 2002 Number 4, 56- 68 .

Catusse, Myriam \& Vairel, Frédéric: Ni tout à fait le même ni tout à fait un autre. Métamorphoses et continuité du régime marocain, in: Maghreb-Machrek, Numéro 175, Printemps 2003, p. 73-91.

Le Monde: www.lemonde.fr

Le Matin du Sahara et du Maghreb: www.lematin.ma

National Democratic Institute (NDI): "Preliminary Statement of the International Observer Delegation to Morocco's 2007 Legislative Elections, Rabat, September 8, 2007 www.moroccodemocracy.org

Tozy, Mohamed: Monarchie et Islam Politique au Maroc, Paris: Presses de la Fondation Nationale des Science Politiques, Paris 1999

Zeghal, Malika: Les islamistes marocaines. Le défi à la monarchie, Casablanca: Editions Le Fennec, Casablanca 2005 